\title{
冷延焼鈍後のフェライトーマルテンサイト二相組織鋼中の マルテンサイトの結晶学的組織解析
}

\author{
吉田 裕美 ${ }^{1) *} \cdot$ 高木 周作 ${ }^{1)} \cdot$ 酒井 翔大 ${ }^{2)} \cdot$ 森戸 茂一 ${ }^{2)} \cdot$ 大庭 卓也 ${ }^{2)}$
}

Crystallographic Analysis of Lath Martensite in Ferrite-Martensite Dual Phase Steel Sheet Annealed after Cold-Rolling Hiromi Yoshida, Shusaku TAKagi, Shota SAKai, Shigekazu Morito and Takuya Оhва

Synopsis : Cold-rolled and annealed ferrite-martensite dual phase (DP) steel sheets are a useful material for automotive applications because of their excellent balance of strength and ductility. Although few research papers have examined the crystallography and microstructure of lath martensite in DP steel, the characteristics of lath martensite have been investigated in single-phase martensitic steel. In the present study, the crystallography and microstructure of lath martensite in a ferrite-martensite dual phase were studied using electron microscopy and electron diffraction analysis, and the crystallographic orientation relationship between the ferrite and martensite was analyzed. The main results are as follows: (1) The lath martensite in DP steel consists of some number of packets, and these packets consist of blocks. This structure is the same as the microstructure of single-phase lath martensite. (2) The habit planes of the martensite laths in a packet tend to be parallel to the closepacked plane of the adjacent ferrite grain, whose fraction is about $30 \%$.

Key words : crystallography; lath martensite; dual phase steel; SEM/EBSD; orientation relationship between ferrite and martensite.

\section{1. 緒言}

マルテンサイト組織は, 古くより焼入れ焼戻し処理を施 した機械構造用鋼や厚鋼板などに用いられてきた。昨今 では，フェライトとマルテンサイトから成る二相組織鋼 (Dual Phase Steel, 以降DP鋼と表記) など所謂複合組織鋼 にも用いられており，厚鋼板・薄鋼板問わず，マルテンサ イトは鋼の組織強化に欠かせない重要な組織のひとつと なっている。超高強度鋼板の開発が盛んな近年では, マル テンサイトの組織構成および力学的特性を評価・把握する 重要性が年々増加している。

従来マルテンサイトの組織構造解析に関する研究は種々 おこなわれており ${ }^{1,2)}$, 特に近年では後方電子散乱罒形解析 法 (Electron Back Scatter Diffraction, 以降EBSD法と表記) を用いた解析により，マルテンサイトの組織構成および結 晶学に関する新たな知見が報告されている3)。鋼のマルテ ンサイトには種々の形態があるが，多くの実用鋼では 0.2 $\mu \mathrm{m}$ 程度の厚みを持つ微細なマルテンサイト晶で構成され ている「ラスマルテンサイト」が出現する。Fig.1にラスマ ルテンサイトの組織構成を模式的に示す。ラスマルテンサ イト組織は, 高温相であるオーステナイトの粒界がそのま ま継承され, 旧オーステナイト粒界で囲まれた領域は, 複
数の同じ晶癖面を持つラスの集団であるパケットによって 分割されている。パケットは複数のブロックから成り, そ のブロックは結晶方位がほぼ同じ微細なマルテンサイトラ ス (以降，ラスと表記) で構成されている。

上述したようなマルテンサイトの組織構成に関する研究 は，その多くがマルテンサイト単一組織に関するものであ り, DP鋼中に存在するラスマルテンサイトに関しては, パ ケットやブロックの有無といったその組織構造解析は殆ど おこなわれていない。これは従来, ラスマルテンサイトが 硬質相であり組織に関係なく変形しないと考えられてきた

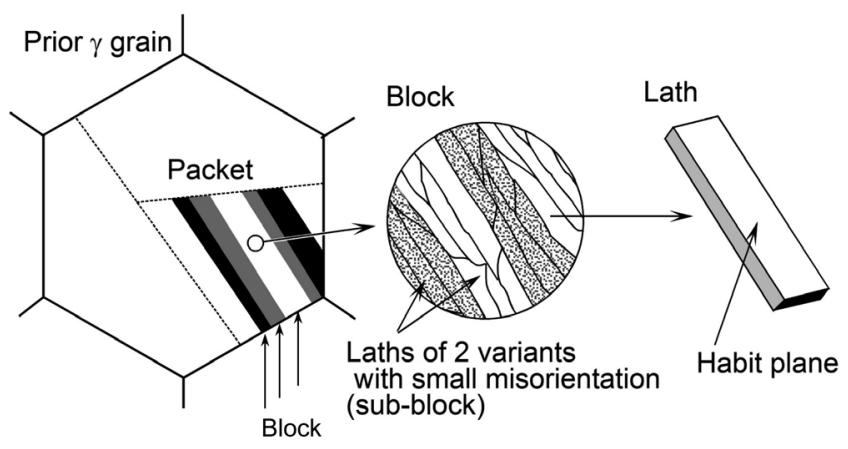

Fig. 1. Schematic illustration showing structure of lath martensite in low carbon steel.

平成 25 年 4 月 1 日受付 平成 25 年 5 月 22 日受理 (Received on Apr. 1, 2013 ; Accepted on May 22, 2013)

1）JFEスチール (株) スチール研究所 (Steel Research Laboratory, JFE Steel Corporation, 1 Kokan-cho Fukuyama Hiroshima 721-8510)

2) 島根大学大学院総合理工学研究科 (Department of Materials Science, Shimane University)

* Corresponding author : E-mail : hirom-yoshida@jfe-steel.co.jp

DOI : http://dx.doi.org/10.2355/tetsutohagane.99.625 
ため, DP 鋼中のマルテンサイトの組織構造に関心が払わ れなかったことが原因と考えられる。例えばSugimoto ら ${ }^{4)}$ やKurihara $5^{5)}$ はDP鋼の延性や破壊, 成形性について調 査しているが，いずれもマルテンサイトの分布形態に関し ての検討であり，マルテンサイト内部組織については考慮 されていない。一方近年, Hasegawa ${ }^{6)}$ はDP鋼中のマル テンサイトの分布と機械的性質の関係について調査し，マ ルテンサイト分率の上昇によりマルテンサイトの塑性歪が 増加することを示している。また, Ueji ら ${ }^{7)}$ はラスマルテ ンサイトの塑性変形組織はラスの並び方によって不均一に なることを示している。破壊挙動に関しても，DP鋼中のマ ルテンサイトが変形して破壊挙動に影響を与えること ${ }^{8)}$ フェライトーマルテンサイト界面でボイドが発生し，これ が連続することで破壊が起こることも示されている ${ }^{9)}$ 。最 近ではS Sato ${ }^{10)}$ が DP 鋼の破面近傍でボイドの発生箇所と マルテンサイトの三次元形態との関係を調ベ，マルテンサ イトのくびれ部でボイドが発生することを示唆する結果を 示している。よって, DP鋼中のマルテンサイトの組織構造 やフェライトーマルテンサイトの結晶方位関係を明らか にし，マルテンサイトの変形に関する理解を深めることに よって，DP鋼の特性を向上できる可能性がある。

このような観点から, Sakai ら ${ }^{11,12)}$ は熱延材および熱延 焼鈍材を用いて DP鋼の組織学的な特徵を明らかにした。 一方薄板分野では，板厚や表面外観・表面性状などの観点 から，熱間圧延 (以降，熱延と表記）後に冷間圧延（以降， 冷延と表記）を施し，これを焼鈍して製造された冷延DP鋼 が実用的に多く用いられる。そこで, 本研究では冷延焼鈍 して得られた DP鋼中のマルテンサイトの組織構成を調査 し, マルテンサイト単一組織鋼中のマルテンサイトとの相 違を明らかにするとともに，フェライトとマルテンサイト の結晶学的な関係を明確にすることを目的とした。

\section{2. 実験方法および組織解析方法}

\section{$2 \cdot 1$ 供試材}

供試材は, C-Si-Mn系の低炭素鋼とした。その成分を Table 1 に示す。Fig.2 には供試材の加工および熱処理履歴

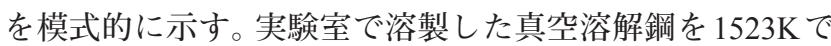
溶体化処理後，オーステナイト域で熱延をおこない，室温 まで空冷して板厚 $5 \mathrm{~mm}$ の熱延材（以降，HR材と表記）を作 製した。この HR 材を研削して板厚 $4 \mathrm{~mm}$ とした後，冷延して 板厚 $2 \mathrm{~mm}$ の冷延板とし，ソルトバスを用いてフェライトー

Table 1. Chemical composition of the steel used (mass\%).

\begin{tabular}{ccccccc}
\hline $\mathrm{C}$ & $\mathrm{Si}$ & $\mathrm{Mn}$ & $\mathrm{P}$ & $\mathrm{S}$ & $\mathrm{Al}$ & $\mathrm{N}$ \\
\hline 0.13 & 1.5 & 2.0 & 0.01 & 0.001 & 0.03 & 0.004 \\
\hline
\end{tabular}

オーステナイト二相域である $1053 \mathrm{~K} て ゙ 1.2 \mathrm{ks}$ 保持後, 水冷 してフェライトーマルテンサイトの DP 鋼サンプル (以降, CA 材と表記) を得た。

\section{$2 \cdot 2$ 組織解析方法}

各試料を切断し, Fig.3に示す圧延面断面（TD面）を耐 水研磨紙，アルミナ懸濁液で機械研磨し，コロイダルシ リカでバフ研磨した。この研磨面に $3 \%$ 硝酸ーアルコー ル (3\%-nital) 液による腐食を施し, 光学顕微鏡観察をお こなった。また, 走査型電子顕微鏡／後方電子散乱困形 解析法 (JEOL JSM 7001FA/EDAX-TSL OIM Ver.5.3, 以降 $\mathrm{SEM} / \mathrm{EBSD}$ 法と表記) で組織観察および結晶方位解析をお こなった。また透過型電子顕微鏡 (JEOL JEM-2010, 以降 TEM と表記) を用いて, 試料の板厚 $1 / 4$ 位置付近の下部組 織観察をおこなった。

ラスマルテンサイト単一組織は, 複数の組織単位が階層 構造を持つことが知られている ${ }^{3,13)}$ 。パケットは, 組織学 的には「同じ晶癖面をもつラスの集団」としているが，結 晶学的には「母相オーステナイトと同一最密面平行関係を 持つラスの集団」とみなすことができる。また，パケット を平行に分割するように存在するブロックについては，ほ ぼ同じ結晶方位を持つラスの集団と定義され，ブロック 境界は $60^{\circ}$ 程の高角粒界とされている。今回用いた供試材 (CA 材) はFig.4に示すように微細なフェライトーマルテ ンサイト組織を有しており, 光学顕微鏡でのパケットの観 察および同定は困難であったため, パケット・ブロック共 SEM/EBSD法で同定をおこなった。

結晶学的に, マルテンサイトの各パケットに含まれる ブロックを構成するラスは晶癖面が同じであり，ラスの $(011)_{\mathrm{M}}$ 共通最密面と $[\overline{1} \overline{1} 1]_{\mathrm{M}}$ 最密方向は，もとのオーステ ナイトの $(111)_{\mathrm{A}}$ 最密面, $[\overline{1} 01]_{\mathrm{A}}$ 最密方向と平行であると

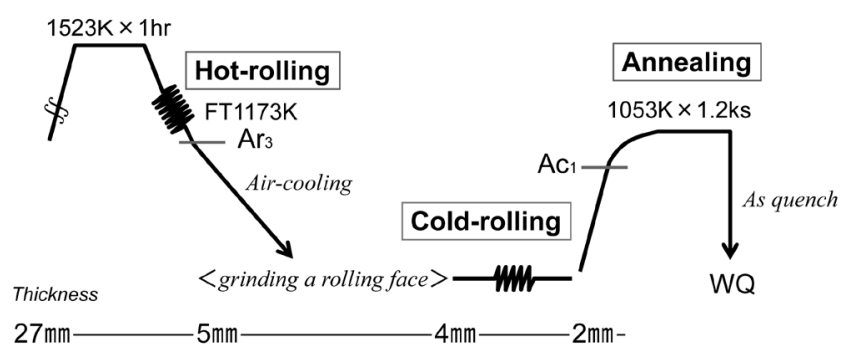

Fig. 2. Rolling conditions and heat-treatment diagram of specimens.

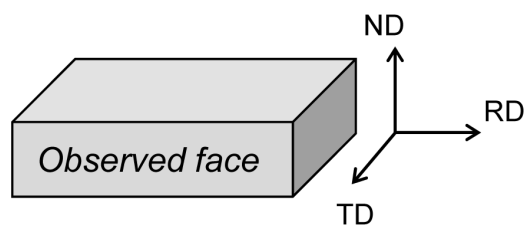

Fig. 3. Schematic illustration showing observed face of specimens. 
するKurdjumov-Sachsの方位関係 (以降，K-S 関係と表記) を基本に考え，\{001 $\}_{\mathrm{M}}$ および $\{011\}_{\mathrm{M}}$ 正極点図 (Pole Figure, 以降PFと表記，下付の A と M, F はそれぞれオーステナイ トとマルテンサイト，フェライトを示す）から，マルテン サイト領域内で共通の最密面を持つ領域をパケットとし て同定すると共に，パケット内で方位差 $5 \circ$ 以内を同じ方 位とみなして 50〜 $60^{\circ}$ 前後の高角粒界を形成する境界をブ ロック境界とした。 $5^{\circ}$ 以内を同一方位とみなした理由は, $\mathrm{K}-\mathrm{S}$ 関係の任意のバリアントにおいて，異なるパケットに 属し最も結晶方位差の小さいバリアント間の結晶方位差が $10.5^{\circ}$ であることと，単一バリアント内の結晶方位差は概ね $5^{\circ}$ 以内とみなせる ${ }^{14)}$ ためである。なお，低炭素鋼の場合， ブロックの内部には $10.5^{\circ}$ の方位差を持つ 2 種のラスが存 在する。これらは結晶学的に異なるラスの集団であり, サ ブブロックと呼ばれる ${ }^{3)}$ が，今回の解析ではサブブロック の判別はおこなわなかった。

旧オーステナイト領域やパケット径は, 画像ソフトウエ ア (Olympus analySIS FIVE) により各粒の面積を測定し， その平均值の平方根を公称粒径とした。ブロック厚 $\mathrm{t} の$ 測 定は, SEM/EBSD法で得られた結晶方位データからパケッ ト中の異なるバリアントのラスの共通最密面法線を求め, 同じデータを使った結晶方位図上に法線の投影線を引き， 次に長さ $L$ の投影線を横切ったブロック境界の数 $n$ を数え た。試料面法線と共通最密面法線の角度を $\theta$ とすると，ブ ロック厚 $t$ は (1) 式で表される;

$$
t=L \times \sin \theta / n
$$

この $\theta$ が $40^{\circ}$ 以上になるパケットを選択し,$L$ $L$ パケッ ト内に収まる条件でブロック厚を測定した。

\section{3. 結果}

\section{$3 \cdot 1$ 試料の組織観察}

Fig.4にCA材の光学顕微鏡組織を示す。CA材はフェラ

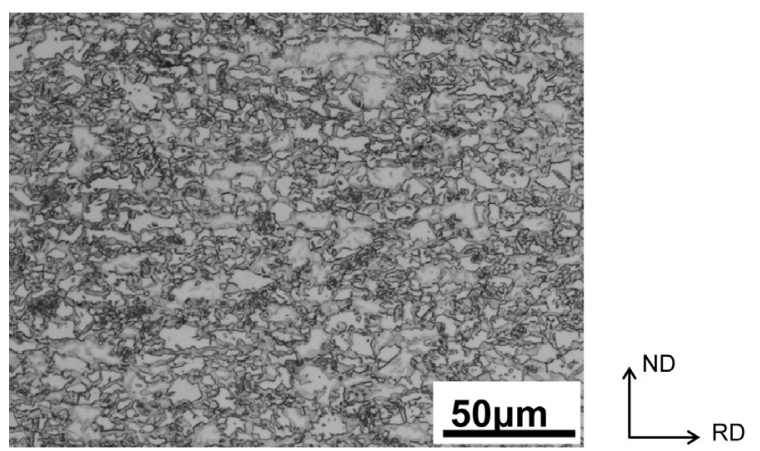

Fig. 4. Optical micrograph of a CA specimen (3\%-nital etched). The specimen contains martensite regions (gray) and ferrite regions (white). The ferrite grain boundaries are not smooth.
イトとマルテンサイトから成る二相組織であり, その面積 分率はフェライト:マルテンサイト $=44: 56$ であった。フェ ライト組織は圧延方向に比較的伸びた形状で，凹凸の多い 界面をもっており，その公称粒径は $4 \mu \mathrm{m}$ であった。マルテ ンサイト組織は, 粗大なものと微細なものが存在し，フェ ライト粒界に割り込むように複雑な形状で存在しているも のが多かったが，一部でフェライト粒内に孤立して存在す るマルテンサイトも観察された。

CA 材を SEM/EBSD解析した結果を Fig.5に示す。(a) は SEM像であり，(b) はこの視野を菊池図形の鮮明度（Image Quality，以降IQ と表記）で示した図である。(c) は (b) 内 に四角枠で囲った領域を拡大したものであり，(d)では， パケットー1をブロック毎に異なる色で示した。(a)に示 されるように, SEM像で一塊に見えるマルテンサイトも， (b) および (c) のIQ像に示すようにミクロには複数個のパ ケットから構成されており, そのパケットは (d) に示され るように1〜数個のブロックで構成されていた。(e) と（f) はそれぞれ (d) 内に示したパケットー1中のブロックの方 位を $\{001\}_{\mathrm{M}} \mathrm{PF}$ と $\{011\}_{\mathrm{M}} \mathrm{PF}$ 上にプロットした四であり，図 中の色は (d) のブロックと対応させている。DP鋼中のマ ルテンサイトも，従来報告されているラスマルテンサイト 単一組織鋼中のマルテンサイトと同じ組織構造を持ち, 組 織内に含まれるブロック間の結晶方位関係もラスマルテン サイト単一組織鋼と同様に, 同じオーステナイト最密面と 共通最密面平行関係を持ち結晶方位差がおよそ $60^{\circ}$ となる ことが明らかとなった。

マルテンサイトの組織構成を詳細に確認するため, TEMで下部組織を観察した。Fig.6にTEM像の一例を示 す。Fig.6 (a) は明視野像であり，(b) は電子回折像である。 Fig.6 (a) 中に矢印で挟んだ領域がラスであり，マルテンサ イトはラスで構成されていることが確認できた。そのラス 厚は 100〜200nm程度であり，通常の低炭素マルテンサイ ト組織と同程度のサイズであった。Fig.6 (b) の電子回折困 形上で共通の $(011)_{\mathrm{M}}$ をつ複数の方位が観察され，その 回折に対応した面とラスの晶癖面が同じであることから， Fig.6 (a) 中に線で囲んだ領域はパケットであり, 複数のブ ロックが存在することがわかった。なお, Fig.6 (b) で水色 の矢印で示した回折点はオーステナイトの $(\overline{1} 1 \overline{1})_{\mathrm{A}}$ を示し ており，マルテンサイトと共にフィルム状残留オーステナ イトの存在を示唆するものである。これらの結果から, DP 鋼中のマルテンサイト組織はマルテンサイト単一組織鋼と 同様の組織構成であることが明らかとなった。また, Fig.6 (a) に示されるようなフェライトに挟まれた比較的微細な マルテンサイトは, その厚さ方向にはパケットが一つし か存在しなかった。すなわち, マルテンサイトの厚さは旧 オーステナイト粒の厚さと考えられ, それがパケット径に ほぼ等しくなっていた。冷延DP鋼中のマルテンサイトは このような特徴も持つ。 
次にブロック厚を調査した。CA材は前述したように粗 大なマルテンサイトと微細なマルテンサイトが混在して いる組織であった。例えばFig.7 に示す領域 A, Bが微細な マルテンサイトであり, 領域 Cが粗大マルテンサイトであ る。旧オーステナイト粒径は粗大なもので $7 \mu \mathrm{m}$, 微細なも ので $2 \mu \mathrm{m}$ であった。そして，それぞれのマルテンサイトブ ロック厚は $0.65 \mu \mathrm{m}$ と $0.46 \mu \mathrm{m}$ であり，旧オーステナイト粒 径が小さくなるに従ってブロック厚は薄くなった。これは Morito ${ }^{15)}$ が Fe-0.2C-2Mn 鋼のマルテンサイト単一組織鋼 で示した結果や, Sakai ら ${ }^{12)}$ が熱延材を焼鈍して作製した DP組織鋼で示した結果と同様の傾向であった。

\section{$3 \cdot 2$ フェライトとマルテンサイトの方位関係解析}

一般にラスマルテンサイトはオーステナイト粒界から生 成することが知られて抢り ${ }^{16)}$ ，マルテンサイト単一組織 鋼ではオーステナイト粒界打よびオーステナイト間の結晶 方位の拘束によるマルテンサイトのバリアント選択則が

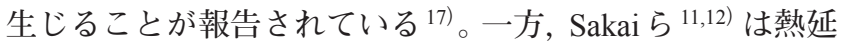
材打よびこの熱延材を焼鈍した素材（以降，熱延焼鈍材と 表記) を用いて, DP 鋼中のマルテンサイトの組織構造打よ びフェライトとマルテンサイトの結晶方位関係について解 析を打こなった結果，マルテンサイトブロックの約半数〜 $40 \%$ は，その最密面である $\{110\}_{\mathrm{M}}$ 面が隣接するフェライ トの $\{110\}_{\mathrm{F}}$ 面と平行関係を有するという特徵を持つこと
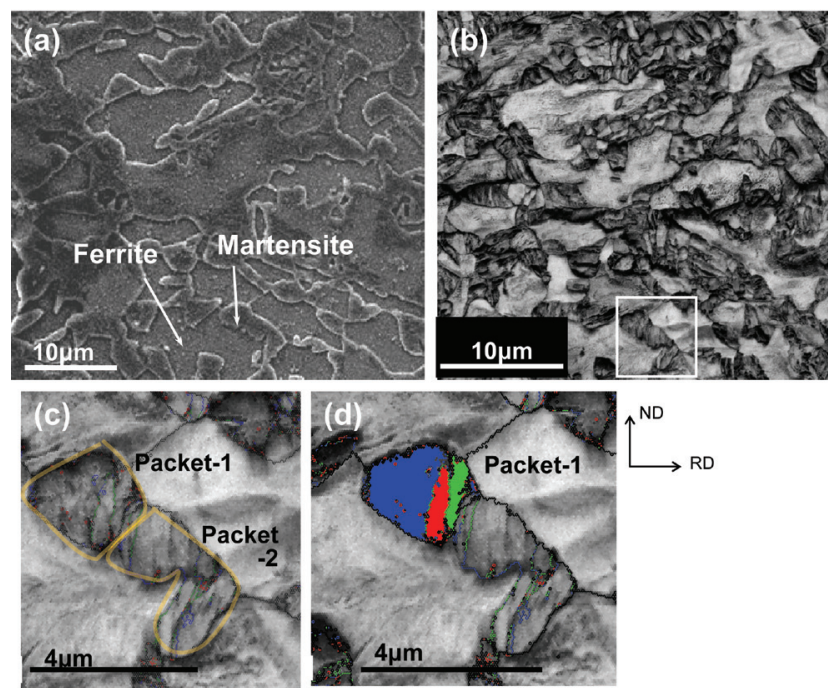

(e)
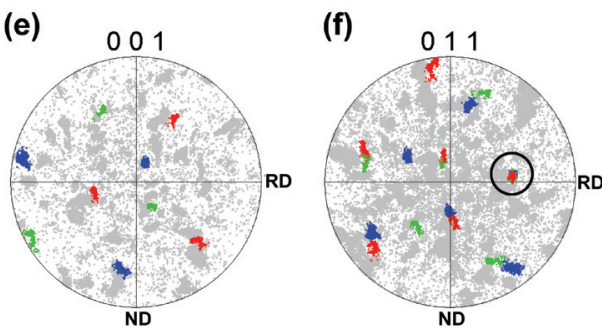

Fig. 5. (a) SEM image, (b) image quality map, (c) magnified map of the white square in (b), (d) block map of Packet-1 with image quality data, (e) $\{001\}_{\mathrm{M}}$ pole figure and (f) $\{011\}_{\mathrm{M}}$ pole figure of a CA specimen.
を明らかにした。この結果から，DP鋼中のマルテンサイト は隣接するフェライトの方位の影響を受ける可能性が考え られる。本研究では，二相域焼鈍から冷却して生成するマ ルテンサイトの結晶方位に及ぼすフェライトの影響を明ら かにするため, CA 材でマルテンサイトとこれに隣接する フェライトとの方位関係を調査した。マルテンサイトのパ ケットおよびブロックを同定したときと同様に，\{001\} $\mathrm{M} P \mathrm{PF}$ および $\{011\}_{\mathrm{M}} \mathrm{PF}$ からマルテンサイトとそれに隣接する フェライト粒の最密面平行関係を確認した。CA材はフェ ライトーマルテンサイト組織で, 全組織に亘って旧オース テナイト粒を確定することが困難であり，且つラスマルテ ンサイトがパケット単位で観察されることから，同定はマ ルテンサイトのパケットを単位とした。マルテンサイトパ ケットに含まれるラスの共通最密面 $\{011\}_{\mathrm{M}}$ とこれに隣接 するフェライトの最密面 $\{011\}_{\mathrm{F}}$ の方位差が $5^{\circ}$ 以内である
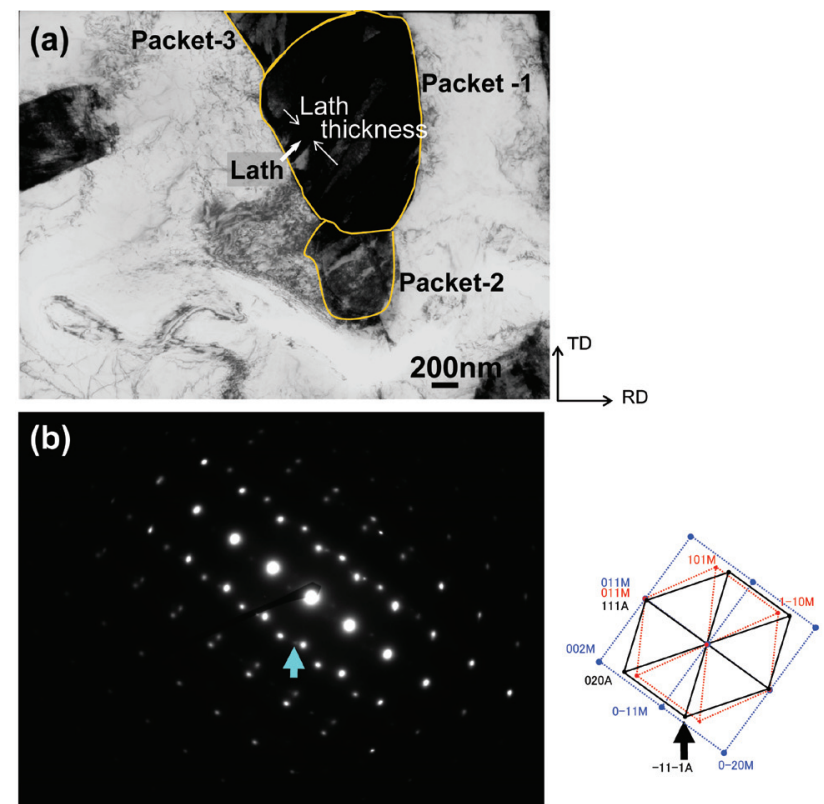

Fig. 6. (a) TEM bright-field image of a CA specimen showing the structure of martensite consisting of several packets, (b) electron diffraction pattern taken from Packet-1. The sky-blue and black arrows indicate $(\overline{1} 1 \overline{1})_{\mathrm{A}}$.

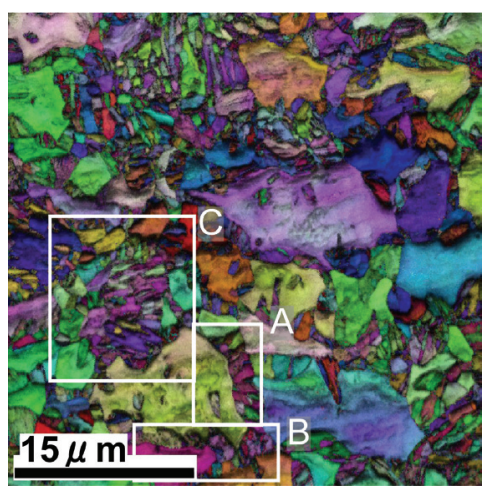

Fig. 7. Orientation image map with image quality data of a CA specimen showing analysis areas A, B, and C. 
ときに,「マルテンサイトパケットの共通最密面とフェラ イトの最密面が平行関係をもつ」と判定した。この判定を, 方位解析が可能犬゙ったパケットに対しておこない，「隣接 するフェライトと最密面が平行であるパケット数/判定 をおこなったパケット数」を求めてマルテンサイトパケッ 卜の共通最密面と隣接するフェライトの最密面が平行で ある割合とした。最密面同士の方位差を $5^{\circ}$ 以内とした理由 は, 単一バリアント内の結晶方位差は概ね $5^{\circ}$ 以内とみなせ る14) ためである。

Fig.5で示した各パケットについて解析した例を Fig.8に 示す。 $\{011\}_{\mathrm{M}} \mathrm{PF}$ 中の黒円は結晶方位図中に白円で示すパ ケットー2の共通最密面を示している。パケットー2の共 通最密面は隣接するフェライト (青色) の最密面と平行で あることが確認できたが，パケットー1では隣接するいず れのフェライトとも最密面平行関係を持っていなかった。 供試材の特徴として, 大きな一つのフェライト粒の周囲 に, 複数の微細なマルテンサイトが存在しており, 観察視 野の中で比較的大きなフェライトの周囲に存在するマルテ ンサイトについて解析したが，中にはIQ值が低く指数付け ができないマルテンサイトもあった。また, Fig.9に示すよ うに，二次元視野中でフェライト粒内に孤立するように存 在するマルテンサイトパケットは，その囲まれているフェ ライトと最密面平行関係を持たない傾向が認められた。

このように方位特定できたマルテンサイトパケットにつ いて解析した結果, その3 割が隣接するフェライトと最密 面平行関係を持っていた。マルテンサイトパケットと隣接
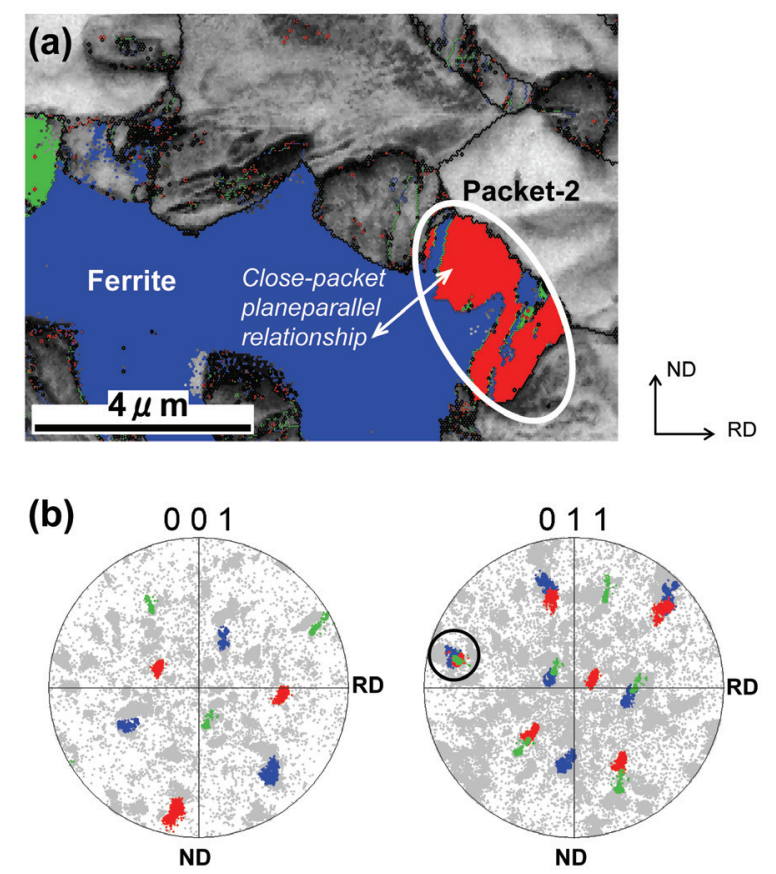

Fig. 8. (a) Orientation image map with image quality data, (b) $\{001\}_{\mathrm{M}}$ and $\{011\}_{\mathrm{M}}$ pole figures of Packet- 2 and ferrite in a CA specimen. Packet-2 has a close-packed plane parallel relationship with the adjacent ferrite grain.
するフェライト同士が最密面平行関係を持つ割合は, Sakai $ら^{11,12)}$ が熱延焼鈍材で同様の調査を扎こなった結果では $40 \%$ であったことから, 熱延焼鈍材に比べて, 今回調査し た冷延焼鈍材のマルテンサイトパケットとその隣接する フェライト間での最密面平行関係は希薄であったと言え る。

\section{$3 \cdot 3$ DP 鋼の三次元組織観察}

DP 鋼のミクロ組織はFig.4に示したように二次元視野で は微細で複雑な粒形状であり, Fig.9に示したように, 二次 元視野中でフェライト粒内に孤立するように存在するマル テンサイトパケットの存在が複数観察された。しかし，己 のようなマルテンサイトは三次元的には周囲の別なフェラ イトと隣接している可能性がある。そのため, CA 材をコ ロイダルシリカ懸濁液でバフ研磨後, 集束イオンビーム加 工で $0.2 \mu \mathrm{m}$ ずつTD方向に掘り下げ, SEM/EBSD観察を繰

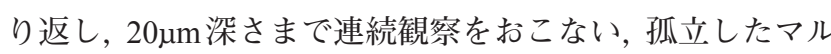
テンサイトが周囲の別なフェライトと隣接する可能性につ いて検討した。集束イオンビーム加工は Gaイオンを用い て $30 \mathrm{kV}, 3 \mathrm{nA}$ の条件で実施し, SEMによる組織観察および EBSD 測定にはFEI Quanta 3D 200 を用いた。

観察結果の一例をFig.10に示す。Fig.10 (a)の上段はIQ 像, 下段は結晶方位図である。No.1の画像内に矢印で示 した黄色いフェライトに着目して視野を掘り下げていく と, No.4の視野でこのフェライト中に異なる方位 (紫色) の領域が出現した。IQ像で見ると同一領域にIQ值が低い ことを示す黒い領域が現れていることから, この紫色の領 域はマルテンサイトであると考えられる。この紫色の領域
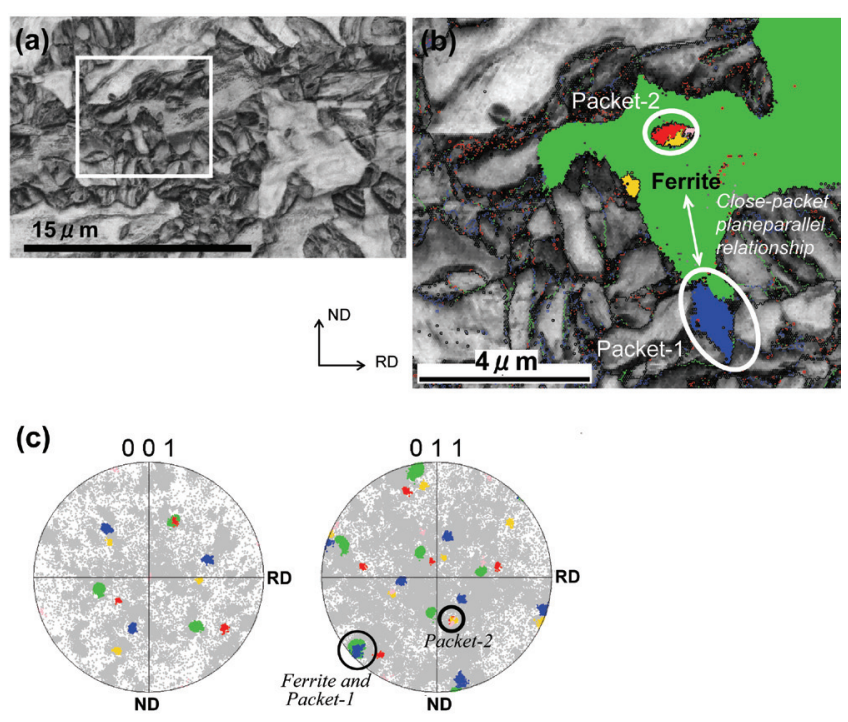

Fig. 9. (a) Image quality map, (b) orientation image map with image quality data, which is a magnified map of the square in (a), and (c) $\{001\}_{\mathrm{M}}$ and $\{011\}_{\mathrm{M}}$ pole figures of Packets- 1 and -2 and ferrite in a CA specimen. Packet-2, which has an island-like shape, does not display a closepacked plane parallel relationship with the adjacent ferrite grain. 
(a)

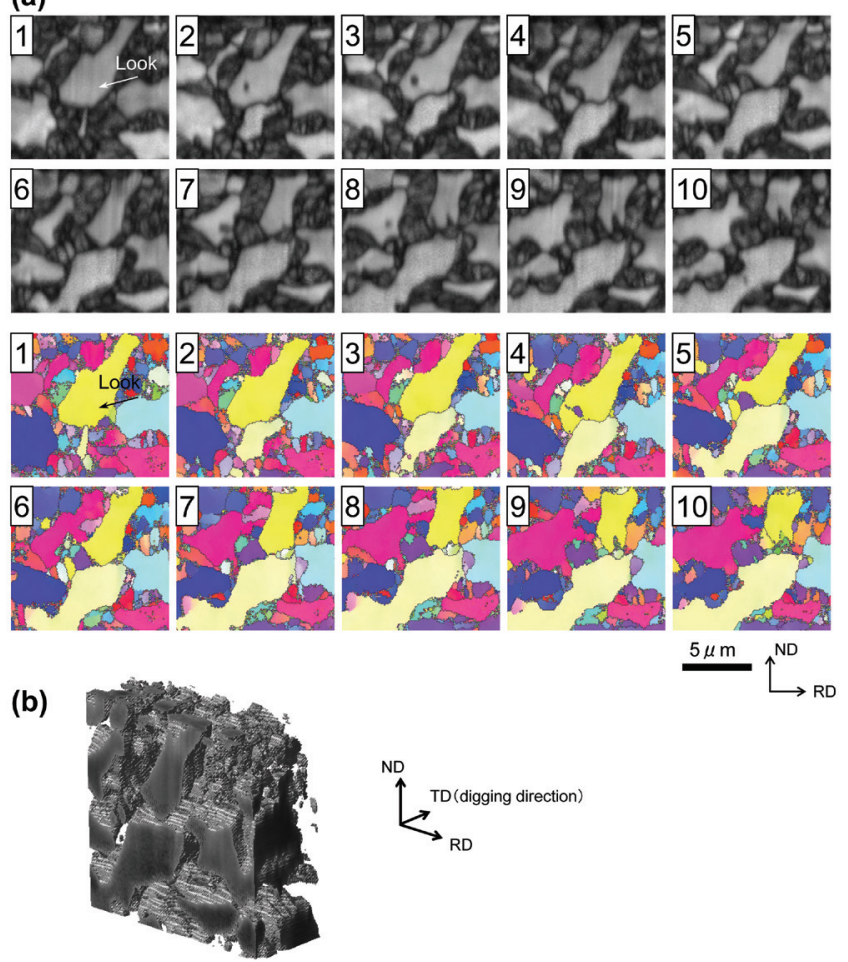

Fig. 10. (a) Image quality map (upper line) and orientation image map (lower line) in a CA specimen. (b) stereogram in which figures No.1-10 are overlaid sequentially.

(a)

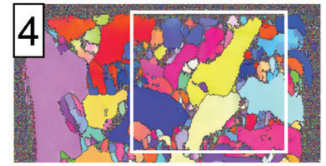

(b)

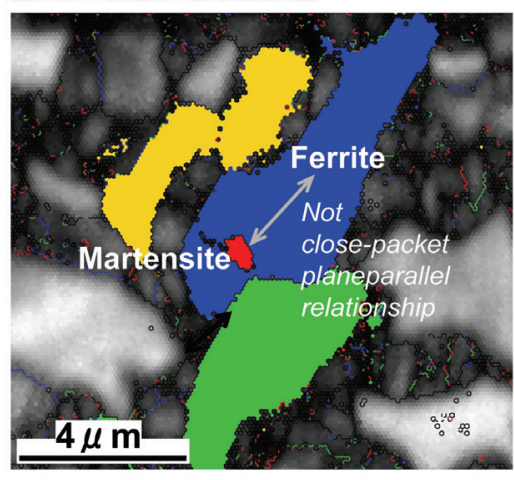

(c)
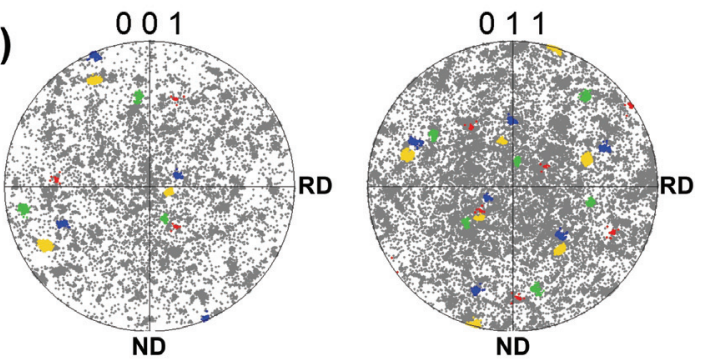

Fig. 11. (a) No.4 orientation image map of Fig.13, (b) orientation image map with image quality data, which is an enlarged map of the square in (a), (c) $\{001\}_{\mathrm{M}}$ and $\{011\}_{\mathrm{M}}$ pole figures showing that a close-packed plane parallel relationship does not exist between the martensite (red) and ferrite (blue) indicated by the double-headed arrow.
が観察されていないNo.2 3 において, 同一視野中にIQ值 の低い領域が存在していることがわかる。これは紫色のマ ルテンサイトによって黄色のフェライトが局所的に塑性変 形を受けていることを示している。さらに掘り下げていく とフェライト粒は形状を変え, マルテンサイトもその領域 が拡大して複数のフェライト粒と隣接するようになった。 No.4の視野で黄色いフェライトとその中に島状に出現し た紫色のマルテンサイトはNo.10の視野位置では, 桃色の 別なフェライトと隣接していた。この結果から, 二次元視 野でフェライト粒内に孤立して存在しているマルテンサイ トも，三次元的に見れば別なフェライトと隣接しているこ とがわかった。また, Fig.10（b）に各視野位置で得られた 粒形状を立体的に示したように, 二次元視野で複雑な形状 をしていた DP鋼の組織は, 三次元的にも粒界が非常に複 雑になっていた。

続いてこの紫色のマルテンサイトについて周囲のフェラ イトとの結晶方位関係を解析した。その結果Fig.11に示す ように, No.4の視野で黄色いフェライトとその中に島状に 出現した紫色のマルテンサイトは最密面平行関係を持って いないが，一方でFig.12に示すようにNo.10の視野では, 柴 色のマルテンサイトは隣の桃色のフェライトと最密面平行 関係を持っていた。この結果から，二次元視野でフェライ

(a)

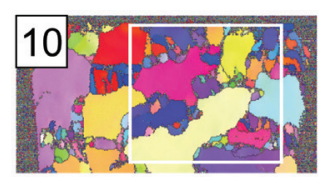

(b)

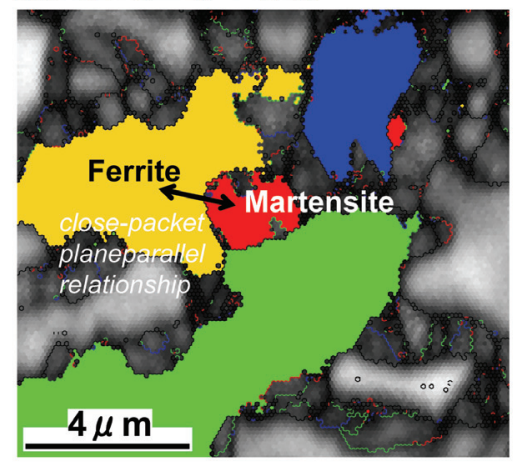

(c)
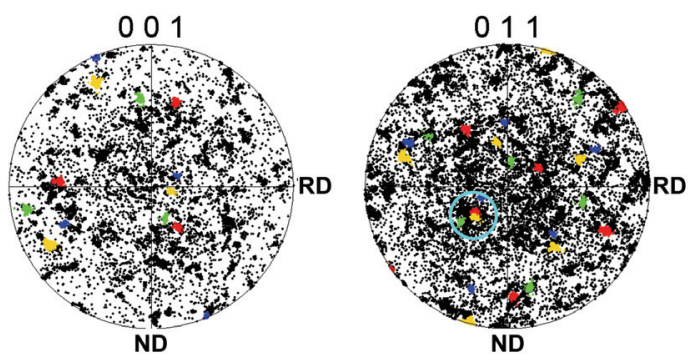

Fig. 12. (a) No.10 orientation image map of Fig.13, (b) orientation image map with image quality data, which is a magnified map of the square in (a), (c) $\{001\}_{\mathrm{M}}$ and $\{011\}_{\mathrm{M}}$ pole figures showing that a close-packed plane parallel relationship exists between the martensite (red) and ferrite (yellow) indicated by the double-headed arrow. 
Table 2. Relationship between prior austenite $(\gamma)$ grain size and block thickness in Fe-C-Mn alloys.

(Chemical compositions of materials: this study and Sakai et al. ${ }^{12)}$ : Fe-0.13C-2Mn, Morito et al. ${ }^{15)}$ : Fe-0.2C-2Mn).

\begin{tabular}{ccccccccccc}
\hline Structure & \multicolumn{3}{c}{ Dual phase } & \multicolumn{3}{c}{ Single phase } \\
\hline Study & \multicolumn{2}{c}{ This study } & \multicolumn{2}{c}{ Sakai et al. } & \multicolumn{4}{c}{ Morito et al. } \\
\hline Prior $\gamma$ grain size $[\mu \mathrm{m}]$ & 2 & 7 & 2.7 & 19 & 6.3 & 14.6 & 55 & 190 & 349 \\
\hline Block thickness $[\mu \mathrm{m}]$ & 0.46 & 0.65 & 0.6 & 0.9 & 1.0 & 1.2 & 1.7 & 2.0 & 3.4 \\
\hline
\end{tabular}

卜粒内に孤立して存在しているマルテンサイトも，三次元 的に見れば別なフェライトと隣接して打り，そのフェライ 卜とは最密面平行関係を持っている可能性が示唆された。

\section{4. 考察}

\section{4 ・1 旧オーステナイト粒径とブロック厚の関係におよぼす組 織の影響}

マルテンサイト単一組織に打いては, ブロック厚の変化 は旧オーステナイト粒径と炭素量に依存することが知られ ている。3章で述べたように, 過去の Morito ら ${ }^{15)}$ の報告や, Sakai ${ }^{12)}$ の報告同様, 本結果も旧オーステナイト粒径が 小さくなるに従ってブロック厚は薄くなる傾向が一致し た。本研究で測定したブロック厚と同じ手法で測定された これらの結果と, 本研究の結果を Table 2 によめ, マルテ ンサイトのブロック厚に及ぼす旧オーステナイト粒径の影 響を Fig.13に示す。旧オーステナイト粒径がマルテンサイ トのブロック厚に及ぼす影響は, マルテンサイト単一組織 鋼とDP鋼とで異なり，同じ旧オーステナイト粒径で比較 すると DP鋼の方がブロック厚は小さくなった。マルテン サイト単一組織鋼を調査したMorito ら ${ }^{15)}$ の結果に依れば, $\mathrm{Fe}-0.2 \% \mathrm{C}-2 \% \mathrm{Mn}$ 鋼では, ブロック厚 $t[\mu \mathrm{m}]$ は旧オース テナイト粒径 $d_{A}[\mu \mathrm{m}]$ に対し，(2) 式が成り立つ;

$$
t=0.006 \times d_{A}+1.08[\mu m]
$$

一方本研究のCA材打よびSakai ら ${ }^{12)}$ の熱延焼鈍材の DP 組織では (3) 式が成り立ち, その傾きから, DP 組織ではマ ルテンサイト単一組織と比較して, 旧オーステナイト粒径 が小さくなるとブロック厚が急激に薄くなることが明らか となった；

$$
t=0.022 \times d_{A}+0.48[\mu m]
$$

この相違の理由として，まず，Morito ら ${ }^{15)} の$ 用いた鋼と 本研究で用いた鋼の成分の違いが考えられる。Morito ら ${ }^{15}$ の供試材は $\mathrm{Fe}-0.2 \% \mathrm{C}-2 \% \mathrm{Mn}$ であるのに対し, 本研究で 用いた供試鋼は, Table 1に示したように Fe- $0.13 \% \mathrm{C}-2 \% \mathrm{Mn}$ $1.5 \% \mathrm{Si}$ である。 DP 鋼のマルテンサイト中の元素濃度は, 焼 鈍中にフェライトとオーステナイトへの元素分配が発生 するために供試材の平均組成とは異なる。 $\mathrm{CA}$ 材は，フェ

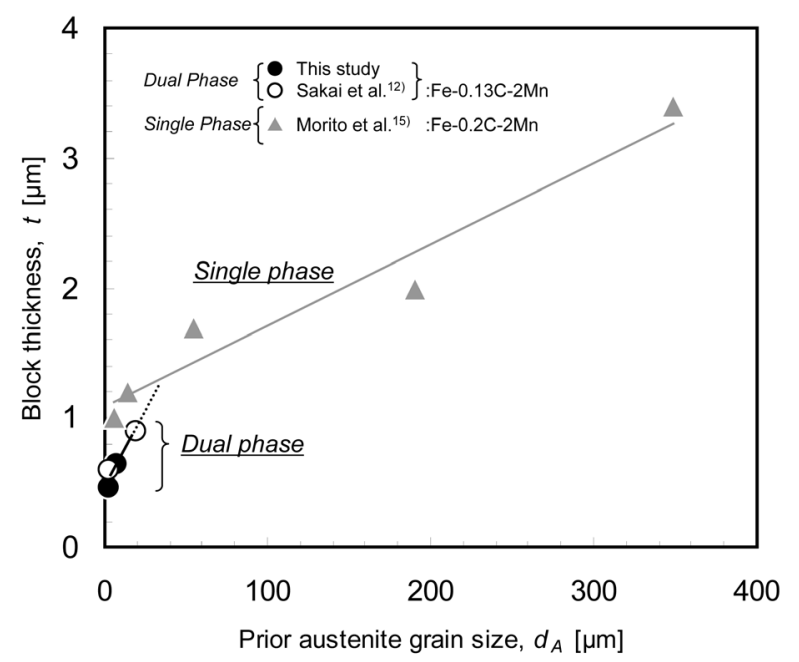

Fig. 13. Relationship between prior austenite $(\gamma)$ grain size and block thickness in Fe-C-Mn alloys.

ライトとマルテンサイトの体積分率が $44: 56$ のDP鋼であ ることから，マルテンサイト中の元素濃度は Table 1 に示し た供試材成分值と異なり, 穴の炭素量はマルテンサイト分 率から計算すると $0.23 \mathrm{mass} \%$ となる。これは Morito ら ${ }^{15)}$ の 供試材と同程度の炭素量と判断できる。一方, Si および $\mathrm{Mn}$ については, Toji ら ${ }^{18)}$ が, 本研究で用いた鋼と同一成分の 鋼を1073Kでフェライトーオーステナイト二相域焼鈍を 打こなった後に焼入れた材料について調査した結果では, 1000 秒の焼鈍では，Mnはオーステナイト中に $2.5 \%$ 程度ま で，Siは定量化されていないが，それぞれフェライト中に 濃化することを示している。この結果と, Si が Moritoら ${ }^{15)}$ の供試材には添加されていないことを勘案すると, CA 材 はMorito ら ${ }^{15)}$ の用いた供試材と比較して, マルテンサイト 中の $\mathrm{Mn}$ 量が $0.5 \%, \mathrm{Si}$ 量が $1 \%$ 程度多いと考えられる。一 方 Maki ら ${ }^{19 ）}$ はパケット径に対する合金元素の影響につい て, 炭素以外の合金元素は組織に大きな影響を及ぼさない としている。今回の本結果と Morito ら ${ }^{15)}$ の供試材における 合金元素濃度の相違では，旧オーステナイト粒径とブロッ ク厚の関係に影響する可能性は低いと考える。

もうひとつの可能性として, オーステナイト粒界の凹凸 がブロック厚におよぼす影響が考えられる。Fig.4 P Fig.11 に示されるように, CA 材の組織はHR材に比べて複雑に入 り組んで打り, Sakai ら ${ }^{12)}$ の結果においても，熱延焼鈍材 
は熱延材に比べ複雑に入り組んでいた。一般的に, ラスマ ルテンサイトはオーステナイト粒界から現れ, 粒界や周囲 のオーステナイトとの結晶学的な拘束条件により生じるブ ロックのバリアントが決定される20)。本試料の場合, オー ステナイトの周りにフェライトが存在しオーステナイトー フェライト界面が平滑でないため, ブロック生成の拘束条 件が単一組織鋼と異なると考えられる。そのため旧オース テナイト粒径ーブロック厚の傾斜が単一組織鋼と DP 鋼と で異なっていたと考えられる。

CA 材の組織は, Sakai ら ${ }^{12)}$ の調查した HR 材と比べて複 雑に入り組んでいた。この異相境界の形態の違いは冷延処 理によるものと考えている。これはSakai ら ${ }^{12)}$ の用いた DP 鋼は熱延板を焼鈍したものであり，二相域焼鈍時にべイナ イトの逆変態もしくはそれに含まれる残留オーステナイト が成長するのに対し，本研究で用いたDP鋼は熱延後に冷 延・焼鈍を施して得られたものであり，焼鈍中に回復・再 結晶したフェライト或いは未再結晶フェライトから微細 なオーステナイト粒が生成打よび成長したと考えられる。 また，フェライトも加工されているため，焼鈍中に回復と 再結晶が起こり，局所的な界面の凹凸が現れたと考えられ る。

\section{$4 \cdot 2$ フェライトとマルテンサイトの方位関係}

次に, Sakai ら ${ }^{12)}$ がおこなった実験で示された熱延焼鈍 材に比べて, 本研究の冷延焼鈍材 (CA 材) のフェライトと マルテンサイト間の最密面平行関係の割合が低くなった理 由について考察する。

第一に冷延・再結晶の影響が考えられる。冷間圧延によ り, 焼鈍前のフェライトに転位が導入され, 加熱および焼 鈍中に二相域でフェライトからオーステナイト変態する 際にフェライトとオーステナイトの方位関係が冷間圧延 で入った転位の影響により, K-S関係からずれた可能性が ある。もしくは，フェライトからオーステナイトに変態し た後に，そのオーステナイト周囲のフェライトが回復・再 結晶により方位変化をしていくことで，フェライトとオー ステナイトの結晶学的方位関係が K-S関係からずれやす くなったことが考えられる。例えばFig.9のPFを見ると， 一つのフェライト粒内部にも方位の広がりが認められる。 Sakai ら ${ }^{12)}$ の熱延焼鈍材ではこのような同一フェライト粒 内の結晶方位分散はさほど見られない。IQ像を重ねて表示 している Fig.7の結晶方位図からは，比較的粗大な一部の フェライト粒内の色が単色になっておらず方位が単一でな いこと，また粒内にはIQ值が低いことを示す黒〜灰色掛 かった箇所が存在して加工組織が残っていることがわか る。すなわち冷間圧延によってフェライトに導入された転 位の影響は無視できず, このようなフェライト粒内の方位 分布は冷延焼鈍材の特徵とも言える。

第二に，二次元視野での観察限界の可能性が挙げられ る。CA材に扣いて二相域焼鈍時のフェライトーオーステ
ナイト組織が微細化し複雑になったため，二次元視野で フェライト粒内に孤立して存在するマルテンサイトパケッ トが，三次元では別なフェライト粒と接していることを Fig.10およびFig.11で示した。そして立体的に接している フェライトとマルテンサイトパケットとの間に最密面平行 関係があることを Fig.12で示した。すなわち, 或る二次元 断面視野で隣接するフェライトとマルテンサイト同士が最 密面平行関係を持たない場合でも，三次元的に接している どこかのフェライトと最密面平行関係を持つ場合があると 言える。本研究の冷延焼鈍材はSakai ら ${ }^{12)}$ が用いた熱延焼 鈍材よりもさらに組織が入り組んでおり, 二次元視野では マルテンサイトと最密面平行関係にある隣接するフェライ トを把握できていない割合が多いと考えられる。冷延焼鈍 材の最密面平行関係の割合は実際には本研究で得られた值 よりも高いことが示唆される。

Shibuta ${ }^{21)}$ は, その場観察およびセクショニングをお こない, マルテンサイトのパケットは粒界面と角度差の小 さい晶癖面が選択される傾向があり，パケット形成に対 して粒界が影響を及ぼすことを示唆している。また, Sato ら 22) は, DP鋼中のマルテンサイトについて三次元観察し, 焼鈍温度条件によりマルテンサイトが様々な形態をとるこ とを示している。組織が微細であることが多い高強度冷延 鋼板におけるDP組織中のマルテンサイトに関して結晶学 的組織解析をする際には, 三次元観察によるフェライト粒 との方位関係の同定が必要であると考える。

\section{5. 結言}

冷延焼鈍後のフェライトーラスマルテンサイト二相組織 鋼とラスマルテンサイト単一組織鋼中のマルテンサイトの 組織構成の相違および二相鋼中のフェライトとラスマルテ ンサイトの結晶学的な関係に関する研究を扢こない, 以下 のことが明らかになった。

(1) 二相鋼に含まれるマルテンサイトは, パケットとそ の中に含まれるブロックから構成され，マルテンサイト単 一組織と同じ構造をもつことが明らかとなった。

(2) マルテンサイトパケットとこれに隣接するフェライ トとの間の方位解析をおこなった結果, パケットの共通最 密面とフェライトの $\{110\}$ 面は $30 \%$ 程度の割合で平行関 係を持っていた。また冷延焼鈍材は熱延焼鈍材と比較し て最密面の平行確率が低かった。その理由について考察し た結果，冷間圧延の影響により，焼入れ前のフェライトと オーステナイトの方位関係が K-S の関係からずれた可能性 が考えられた。さらに, 二次元観察ではマルテンサイトが 隣接するフェライトと最密面平行関係を有していない場 合でも, 三次元解析により, 最密面平行関係を有する別の フェライトと隣接している場合が確認された。このような 方位解析の実施には，二次元のみならず三次元的に組織を 
考える必要性が示唆された。

（3）熱延板を冷延焼鈍した DP 鋼では, 従来のマルテンサ イト単一組織鋼での結果に比べ，マルテンサイトのブロッ ク厚が薄くなる傾向があった。この原因は冷間圧延組織を 焼鈍することにより，オーステナイト粒界の凹凸が多くな るためと考えられる。

\section{謝辞}

本研究の一部 (三次元組織解析) は, 東北大学 金属材料 研究所と島根大学との共同研究 (森戸, 課題番号 08K0095, 09K0016）による結果を使用させていただきました。

\section{文献}

1 ) G.Krauss: Mater. Sci. Eng. A, 273-275(1999), 40.

2 ) 西山善次 : マルテンサイト変態, 丸善, 東京, (1979).

3 ) S.Morito, H.Tanaka, R.Konishi, T.Furuhara and T.Maki: Acta Mater, 51(2003), 1789.

4 ) K.Sugimoto, T.Sakaki, T.Fukusato and O.Miyagawa: Tetsu-toHagané, 71(1985), 994.

5 ) K.Kurihara, Y.Hosoya and K.Nakaoka: Tetsu-to-Hagané, 68(1982), 1195.

6 ) K.Hasegawa, Y.Toji, H.Minami, H.Ikeda, T.Morikawa and K.Higashida: Tetsu-to-Hagané, 98(2012), 320.

7 ) R.Ueji, N.Tsuji, Y.Minamino and Y.Koizumi: Acta Mater, 50(2002), 4177.
8 ) M.Kurita, K.Sotoyama, S.Nomura and K.Kunishige: Tetsu-toHagané, 81(1995), 1091.

9 ) D.Kondo, K.Kunishige and R.Ueji: Tetsu-to-Hagané, 92(2006), 457.

10) N.Sato, M.Ojima, Y.Tomota and Y.Adachi: CAMP-ISIJ, 24(2011), 1029, CD-ROM.

11) S.Sakai, S.Morito, T.Oba, H.Yoshida and S.Takagi: CAMP-ISIJ, 22(2009), 1305, CD-ROM.

12) S.Sakai, S.Morito, T.Oba, H.Yoshida and S.Takagi: Netsu Shori, 51(2011), 233.

13) S.Morito, H.Saito, T.Ogawa, T.Furuhara and T.Maki: ISIJ Int., 45(2005), 91

14) S.Morito, X.Huang, T.Furuhara, T.Maki and N.Hansen: Acta Mater, 54(2006), 5323.

15) S.Morito, H.Yoshida, T.Maki and X.Huang: Mater. Sci. Eng. A, 438440, (2006), 237.

16) K.Tsuzaki and T.Maki: J. Jpn. Inst. Met., 45(1981), 126.

17) S.Morito, R.Igarashi, K.Kamiya, T.Ohba and T.Maki: Material Science Forum, 638-642(2010), 1459.

18) Y.Toji, T.Yamashita, K.Nakajima, K.Okuda, H.Matsuda, K.Hasegawa and K.Seto: ISIJ Int., 51(2011), 818.

19) T.Maki, K.Tsuzaki and I.Tamura: Trans. Iron Steel Inst. Jpn., 20(1980), 207

20) S.Morito, J.Nishikawa, T.Ohba, T.Furuhara and T.Maki: G.B. Olson, D.S. Liberman, A. Saxena (Eds.), Proc. of ICOMAT 2008, TMS, Warrendale, PA, (2009), 649.

21) N.Shibuta, S.Nambu, K.Asakura, J.Inoue and T.Koseki: CAMP-ISIJ, 24(2011), 1011, CD-ROM.

22) N.Sato, Y.Adachi, H.Kawata and K.Kaneko: ISIJ Int., 52(2012), 1362. 